\title{
A NOTE ON THE INTERVAL FUNCTION OF A DISCONNECTED GRAPH
}

\author{
Manoj Changat \\ Ferdoos Hossein Nezhad \\ Department of Futures Studies \\ University of Kerala \\ Trivandrum-695034, India \\ e-mail: mchangat@gmail.com \\ ferdows.h.n@gmail.com \\ Henry Martyn Mulder \\ Econometrisch Instituut \\ Erasmus Universiteit \\ Rotterdam, the Netherlands \\ e-mail: hmmulder@ese.eur.nl \\ AND

\section{N. NARAYANAN} \\ Department of Mathematics \\ IIT Madras, Chennai-600 036, India \\ e-mail: narayana@gmail.com
}

\begin{abstract}
In this note we extend the Mulder-Nebeský characterization of the interval function of a connected graph to the disconnected case. One axiom needs to be adapted, but also a new axiom is needed in addition.
\end{abstract}

Keywords: interval function, transit function, axiomatic characterization, disconnected graph.

2010 Mathematics Subject Classification: 05C12, 05C38, 05 C05. 
[1] K. Balakrishnan, M. Changat, A.K. Lakshmikuttyamma, J. Mathew, H.M. Mulder, P.G. Narasimha-Shenoi and N. Narayanan, Axiomatic characterization of the interval function of a block graph, Discrete Math. 338 (2015) 885-894. doi:10.1016/j.disc.2015.01.004

[2] M. Changat, S. Klavžar and H.M. Mulder, The all-paths transit function of a graph, Czechoslovak Math. J. 51 (2001) 439-448. doi:10.1023/A:1013715518448

[3] M. Changat and J. Mathew, Induced path transit function, monotone and Peano axioms, Discrete Math. 28 (2004) 185-194. doi:10.1016/j.disc.2004.02.017

[4] M. Changat, H.M. Mulder and G. Sierksma, Convexities related to path properties on graphs, Discrete Math. 290 (2005) 117-131. doi:10.1016/j.disc.2003.07.014

[5] M. Changat, J. Mathew and H.M. Mulder, Induced path transit function, betweenness and monotonicity, Electron. Notes Discrete Math. 15 (2003) 60-63. doi:10.1016/S1571-0653(04)00531-1

[6] M. Changat, J. Mathew and H.M. Mulder, The induced path function, monotonicity and betweenness, Discrete Appl. Math. 158 (2010) 426-433. doi:10.1016/j.dam.2009.10.004

[7] M. Changat, A.K. Lakshmikuttyamma, J. Mathew, I. Peterin, P.G. NarasimhaShenoi, G. Seethakuttyamma and S. Špacapan, A forbidden subgraph characterization of some graph classes using betweenness axioms, Discrete Math. 313 (2013) 951-958. doi:10.1016/j.disc.2013.01.013

[8] P. Duchet, Convex sets in graphs II. Minimal path convexity, J. Combin. Theory Ser. B 44 (1988) 307-316. doi:10.1016/0095-8956(88)90039-1

[9] M.A. Morgana and H.M. Mulder, The induced path convexity, betweenness and svelte graphs, Discrete Math. 254 (2002) 349-370. doi:10.1016/S0012-365X(01)00296-5

[10] H.M. Mulder, The Interval Function of a Graph (MC Tracts 132, Mathematisch Centrum, Amsterdam, 1980).

[11] H.M. Mulder, Transit functions on graphs (and posets), in: Convexity in Discrete Structures (M. Changat, S. Klavžar, H.M. Mulder, A. Vijayakumar, Eds.), Lecture Notes Ser. 5, Ramanujan Math. Soc. (2008) 117-130.

[12] H.M. Mulder and L. Nebeský, Axiomatic characterization of the interval function of a graph, European J. Combin. 30 (2009) 1172-1185. doi:10.1016/j.ejc.2008.09.007

[13] L. Nebeský, A characterization of the interval function of a connected graph, Czechoslovak Math. J. 44 (1994) 173-178. 
[14] L. Nebeský, Characterizing the interval function of a connected graph, Math. Bohem. 123 (1998) 137-144.

[15] L. Nebeský, The interval function of a connected graph and a characterization of geodetic graphs, Math. Bohem. 126 (2001) 247-254.

[16] L. Nebeský, A characterization of the interval function of a (finite or infinite) connected graph, Czechoslovak Math. J. 51 (2001) 635-642. doi:10.1023/A:1013744324808

[17] L. Nebeský, The induced paths in a connected graph and a ternary relation determined by them, Math. Bohem. 127 (2002) 397-408.

Received 21 May 2016

Revised 13 September 2016

Accepted 14 September 2016 